\title{
Performance analysis on telecommunication companies in malaysia with TOPSIS model
}

\author{
Lam Weng Hoe ${ }^{1}$, Lam Weng Siew ${ }^{2}$, Liew Kah Fai ${ }^{3}$ \\ ${ }^{1,2,3}$ Department of Physical and Mathematical Science, Faculty of Science, Universiti Tunku Abdul Rahman, \\ Kampar Campus, Malaysia \\ ${ }^{1,2,3}$ Centre for Mathematical Sciences, Centre for Business and Management, Universiti Tunku Abdul Rahman, \\ Kampar Campus, Malaysia
}

\begin{abstract}
Article Info
Article history:

Received Nov 15, 2018

Revised Dec 16, 2018

Accepted Dec 30, 2018

\section{Keywords:}

Financial Ratios

Optimal Solution

Ranking

Telecommunication Company

TOPSIS Model

ABSTRACT

Emergence of telecommunication companies is springing up due to the high demand from the consumers. The invention of telecommunication has made the world more knowledgeable as information can be transmitted easily. Based on the past studies, telecommunication is not commonly investigated especially in financial management field. Thereore, this study aims to propose a conceptual framework to evaluate, compare and rank the financial performance of the listed telecommunication companies in Malaysia using TOPSIS model. Financial ratios are employed to examine the financial performance of the telecommunication companies. The data of this study consists of DIGI, MAXIS, AXIATA and TM which are listed telecommunication companies in Malaysia stock market. The results of this study show that DIGI achieves the first ranking, followed by MAXIS, AXIATA and TM within the study period of year 2011-2015. This study is significant because it helps to evaluate, compare and rank the financial performance of the listed telecommunication companies in Malaysia with the proposed conceptual framework based on TOPSIS model.
\end{abstract}

Copyright $@ 2019$ Institute of Advanced Engineering and Science. All rights reserved.

\section{Corresponding Author:}

Lam Weng Siew,

Department of Physical and Mathematical Science,

Faculty of Science, Universiti Tunku Abdul Rahman, Kampar Campus,

Jalan Universiti, Bandar Barat, 31900 Kampar, Perak, Malaysia.

Email: lamws@utar.edu.my

\section{INTRODUCTION}

Telecommunication is growing nowadays due to high demand from the customers. The changing in business environment enables telecommunication and IT industry to combine and work out together such as management information system (MIS) so that the industry is more service-oriented [1]. Plenty mobile data plan and services are designed according to modern people lifestyle. Since the company desires to upgrade its system, network speed as well as coverage, it requires a huge amount of financial support to achieve the goal. In Malaysia, telecommunication is not commonly investigated especially in financial management field. Therefore, the financial performance of the telecommunication companies in Malaysia should be investigated. The financial ratio analysis has been adopted by different researchers in determining the financial performance of the companies [2-14].

Technique Order of Preference by Similarity to Ideal Solution (TOPSIS) is a decision tool which aims to solve multi-criteria decision making problem [15]. TOPSIS model aims to determine the alternative which is closest to the best ideal solution and farthest from the worst ideal solution in a multi-dimensional computing space [16, 17]. It has been applied extensively in the various areas such as financial companies [2], automotive industry [9], lodging companies [10], textile firms [12] and pension companies [18]. Each alternative will be assigned a score of relative closeness to the ideal solution by using 
TOPSIS model. The alternative with the highest score of relative closeness to the ideal solution will be considered as the best alternative among all the alternatives available. TOPSIS model is proposed in this study since it can evaluate, compare and rank the overall financial performance of the telecommunication companies in Malaysia by considering the important financial ratios.

The objective of this paper is to propose a conceptual framework to evaluate, compare and rank the financial performance of the listed telecommunication companies in Malaysia with TOPSIS model. DIGI, MAXIS, AXIATA and TM are the listed telecommunication companies in Malaysia stock market. The rest of the paper is organized as follows. The next section discusses about the data and methodology of the study. Section 3 presents the empirical results of this study. Section 4 concludes the paper.

\section{DATA AND METHODOLOGY}

The data of this study consists of four listed telecommunication companies in Malaysia stock market as shown in Table 1.

Table 1. Listed Telecommunication Companies in Malaysia Stock Market

\begin{tabular}{lcc}
\hline \multicolumn{1}{c}{ Company Name } & Abbreviations & Code \\
\hline AXIATA GROUP BERHAD [S] & AXIATA & 6888 \\
DIGI.COM BERHAD [S] & DIGI & 6947 \\
MAXIS BERHAD [S] & MAXIS & 6012 \\
TELEKOM MALAYSIA BERHAD [S] & TM & 4863 \\
\hline
\end{tabular}

Source: [19]

The financial ratios in this study are obtained from the respective companies' financial annual report from year 2011 until 2015 as shown from (1) to (7) [20].

$$
\text { Current ratio }=\frac{\text { Current assets }}{\text { Current liabilitie } \mathrm{s}}
$$

$$
\text { Return on equity }=\frac{\text { Net profit }}{\text { Total shareholders' equity }} \times 100 \%
$$

Profit margin $=\frac{\text { Net profit }}{\text { Sales }} \times 100 \%$

Debt to equity ratio $=\frac{\text { Total liabilitie s }}{\text { Total shareholders' equity }}$

$$
\text { Earnings per share }=\frac{\text { Net profit }}{\text { Number of shares }}
$$

Dividend yield $=\frac{\text { Dividend per share }}{\text { Market price per share }} \times 100 \%$

$$
\text { Price earnings ratio }=\frac{\text { Market price per share }}{\text { Earnings per share }}
$$

The best ideal alternatives seek the financial ratios that need to be minimized are debt to equity ratio and PE ratio. On the other hand, current ratio, ROE, profit margin, EPS and dividend yield are the financial ratios that should be maximized. TOPSIS model aims to determine the alternative which is closest to the best ideal solution and farthest from the worst ideal solution as shown:

Performance analysis on telecommunication companies in malaysia with TOPSIS model (Lam Weng Hoe) 
Step 1: Formation of decision matrix $\left(\left(_{i j}\right)_{m \times n}\right)$ :

Construct an evaluation matrix as shown below.

$$
\left(x_{i j}\right)_{m \times n}=\left[\begin{array}{cccc}
x_{11} & x_{12} & \ldots & x_{1 n} \\
x_{21} & x_{22} & \ldots & x_{2 n} \\
\cdot & & & \cdot \\
\cdot & & & \cdot \\
\cdot & & & \cdot \\
x_{m 1} & x_{m 2} & \ldots & x_{m n}
\end{array}\right]
$$

Step 2: Formation of normalized decision matrix:

Construct normalized decision matrix $R=\left(r_{i j}\right)_{m \times n}$ as shown below.

$$
r_{i j}=\frac{x_{i j}}{\sqrt{\sum_{i=1}^{m} x_{i j}^{2}}}, i=1,2, \ldots, m, j=1,2, \ldots, n
$$

$$
\mathbf{R}=\left(r_{i j}\right)_{m \times n=}\left[\begin{array}{cccc}
r_{11} & r_{12} & \ldots & r_{1 n} \\
r_{21} & r_{22} & \ldots & r_{2 n} \\
\cdot & & & \cdot \\
\cdot & & & \cdot \\
\cdot & & & \cdot \\
r_{m 1} & r_{m 2} & \ldots & r_{m n}
\end{array}\right]
$$

Step 3: Formation of nominal normalized decision matrix (T).

$$
\mathbf{T}=\left(t_{i j}\right)_{m \times n}=\left(w_{j} r_{i j}\right)_{m \times n}, i=1,2, \ldots, m
$$

$$
\text { Where } w_{j}=\frac{W_{j}}{\sum_{j=1}^{n} W_{j}}, j=1,2, \ldots, n
$$

$\sum_{j=1}^{n} w_{j}=1$ and $W_{j}$ is the original weight given to the indicator ${ }^{w_{j}}, \mathrm{j}=1,2, \ldots, \mathrm{n}$.

$$
\mathbf{T}=\left[\begin{array}{cccc}
w_{1} r_{11} & w_{2} r_{12} & \ldots & w_{n} r_{1 n} \\
w_{1} r_{21} & w_{2} r_{22} & \ldots & w_{n} r_{2 n} \\
\cdot & & & \cdot \\
\cdot & & & \cdot \\
\cdot & & & \cdot \\
w_{1} r_{m 1} & w_{2} r_{m 2} & \ldots & w_{n} r_{m n}
\end{array}\right]
$$

Step 4: Determination of the best ideal ( ${ }^{A_{b}}$ ) solution and the worst ideal ( ${ }^{A_{w}}$ ) solution: 


$$
\begin{aligned}
& A_{b}=\left\{\left\langle\min \left(t_{i j} \mid i=1,2, \ldots, m\right) \mid j \in J_{-}\right\rangle,\right. \\
& \left.\left\langle\max \left(t_{i j} \mid i=1,2, \ldots, m\right) \mid j \in J_{+}\right\rangle\right\} \equiv\left\{t_{b j} \mid j=1,2, \ldots, n\right\}, \\
& A_{w}=\left\{\left\langle\max \left(t_{i j} \mid i=1,2, \ldots, m\right) \mid j \in J_{-}\right\rangle,\right. \\
& \left.\left\langle\min \left(t_{i j} \mid i=1,2, \ldots, m\right) \mid j \in J_{+}\right\rangle\right\} \equiv\left\{t_{w j} \mid j=1,2, \ldots, n\right\},
\end{aligned}
$$

Step 5: Calculation of separation measures for each alternative based on the best ideal solution $d_{i b}$ and worst ideal solution $d_{i w}$.

$$
\begin{aligned}
& d_{i b}=\sqrt{\sum_{j=1}^{n}\left(t_{i j}-t_{b j}\right)^{2}}, i=1,2, \ldots, m \\
& d_{i w}=\sqrt{\sum_{j=1}^{n}\left(t_{i j}-t_{w j}\right)^{2}}, i=1,2, \ldots, m
\end{aligned}
$$

Step 6: Calculation of relative distances from the ideal solution ${ }_{i w}$ :

$$
s_{i w}=\frac{d_{i w}}{d_{i b}+d_{i w}}, 0 \leq s_{i w} \leq 1, i=1,2, \ldots, m
$$

Step 7: Alternatives are calculated and ranked depending on their proximity to the ideal solution. Rank the alternatives according to $s_{i w}(i=1,2, \ldots, m)$ in descending order and select the alternative with the highest value of $s_{i w}$ which is closest to 1 .

\section{EMPIRICAL RESULTS}

Table 2, Table 3 and Table 4 present the multi-criteria decision making matrix, normalized decision matrix and weighted normalized decision matrix respectively. The positive ideal solution and negative ideal solution for each decision criterion are presented in Figure 1.

Table 2. Multi-Criteria Decision Making Matrix

\begin{tabular}{cccccccc}
\hline Company & Current ratio & ROE $(\%)$ & $\begin{array}{c}\text { Profit margin } \\
(\%)\end{array}$ & $\begin{array}{c}\text { Debt to } \\
\text { equity ratio }\end{array}$ & EPS & $\begin{array}{c}\text { Dividend } \\
\text { yield }(\%)\end{array}$ & PE ratio \\
\hline AXIATA & 8.025 & 13.664 & 140.712 & 0.079 & 0.278 & 3.567 & 153.793 \\
DIGI & 222.255 & 206.289 & 100.010 & 0.001 & 0.225 & 4.348 \\
MAXIS & 44.441 & 6.627 & 85.293 & 0.288 & 0.253 & 5.843 & 23.239 \\
TM & 1.075 & 14.649 & 9.883 & 2.273 & 0.255 & 3.689 & 23.735 \\
\hline
\end{tabular}

Table 3. Normalized Decision Matrix (2011-2015)

\begin{tabular}{llllllll}
\hline Company & Current ratio & ROE $(\%)$ & $\begin{array}{l}\text { Profit margin } \\
(\%)\end{array}$ & $\begin{array}{l}\text { Debt to } \\
\text { equity ratio }\end{array}$ & EPS & $\begin{array}{l}\text { Dividend } \\
\text { yield }(\%)\end{array}$ & PE ratio \\
\hline AXIATA & 0.03538 & 0.06590 & 0.72981 & 0.03456 & 0.54829 & 0.40039 & 0.96345 \\
DIGI & 0.97996 & 0.99481 & 0.51871 & 0.00042 & 0.44404 & 0.48800 & 0.14558 \\
MAXIS & 0.19595 & 0.03196 & 0.44238 & 0.12572 & 0.49893 & 0.65581 & 0.16873 \\
TM & 0.00474 & 0.07064 & 0.05126 & 0.99146 & 0.50327 & 0.41407 & 0.14869 \\
\hline
\end{tabular}


Table 4. Weighted Normalized Decision Matrix (2011-2015)

\begin{tabular}{|c|c|c|c|c|c|c|c|}
\hline Company & Current ratio & $\operatorname{ROE}(\%)$ & $\begin{array}{l}\text { Profit margin } \\
(\%)\end{array}$ & $\begin{array}{l}\text { Debt to } \\
\text { equity ratio }\end{array}$ & EPS & $\begin{array}{l}\text { Dividend } \\
\text { yield }(\%)\end{array}$ & PE ratio \\
\hline AXIATA & 0.00505 & 0.00941 & 0.10426 & 0.00494 & 0.07833 & 0.05720 & 0.13764 \\
\hline DIGI & 0.13999 & 0.14212 & 0.07410 & 0.00006 & 0.06343 & 0.06971 & 0.02080 \\
\hline MAXIS & 0.02799 & 0.00457 & 0.06320 & 0.01796 & 0.07128 & 0.09369 & 0.02410 \\
\hline TM & 0.00068 & 0.01009 & 0.00732 & 0.14164 & 0.07190 & 0.05915 & 0.02124 \\
\hline
\end{tabular}

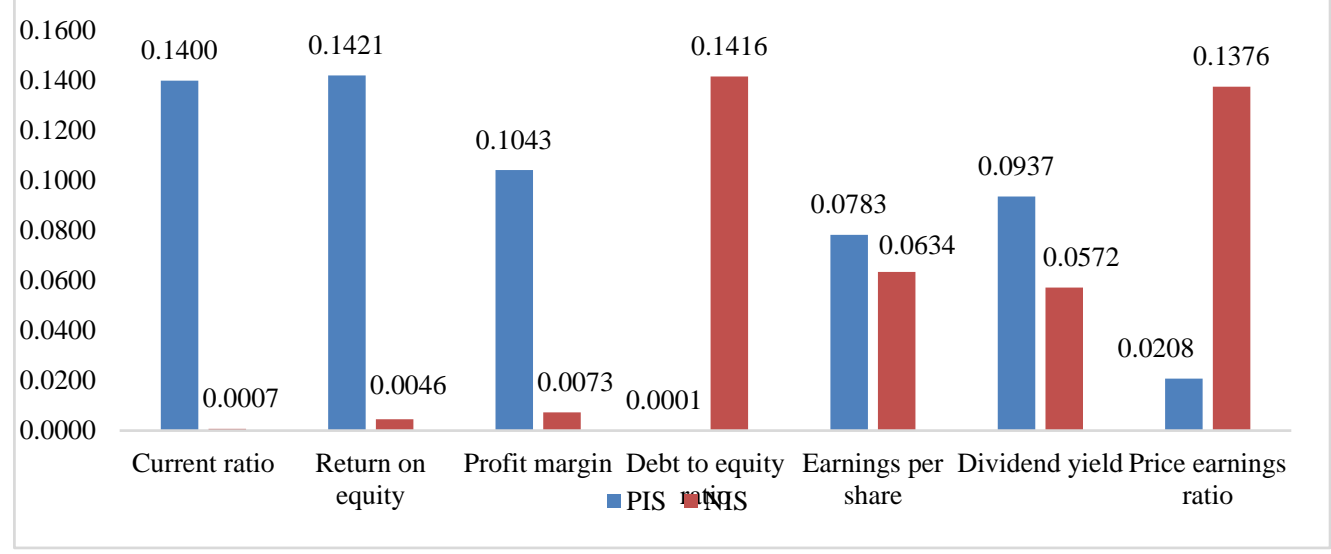

Figure 1. Best ideal (Ab) and worst ideal (Aw) solutions

As shown in Figure 1, the Aw that determined by the TOPSIS model for current ratio, ROE, profit margin, debt to equity ratio, EPS, dividend yield and PE ratio are $0.0007,0.0046,0.0073,0.1416,0.0634$, 0.0572 and 0.1376 respectively. On the other hand, the $\mathrm{Ab}$ for current ratio, ROE, profit margin, debt to equity ratio, EPS, dividend yield and PE ratio are $0.1400,0.1421,0.1043,0.0001,0.0783,0.0937$ and 0.0208 respectively. The best ideal and worst ideal solutions for each finantial ratio serve as the benchmark to the telecommunication companies for further improvement.

In this study, the distance of the telecommunication companies from the best ideal solution $d_{i b}$ and the distance of all decision alternatives from the worst ideal solution $d_{i w}$ are calculated by using the Equations (15) and (16) respectively. Figure 2 and Figure 3 presents the distance of all alternatives from the worst ideal solution (diw) and the distance of all alternatives from the best ideal solution (dib) respectively.

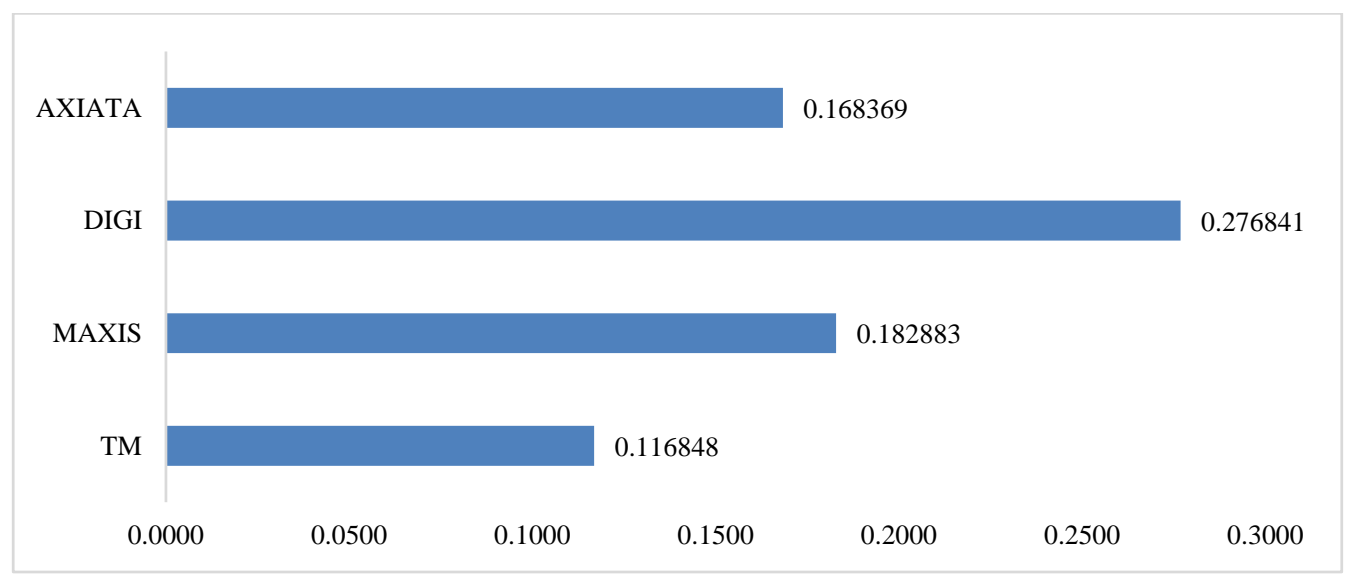

Figure 2. Distance of the alternatives from the worst ideal solution (diw) 


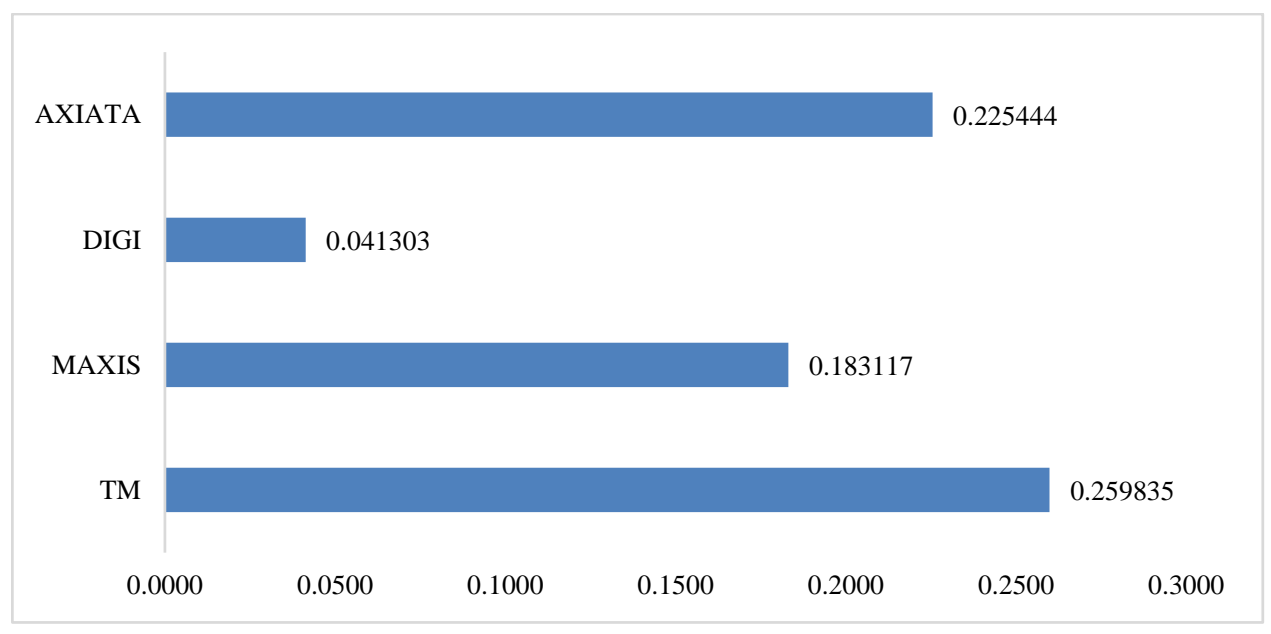

Figure 3. Distance of the alternatives to the best ideal solution (dib)

According to Figure 2 and Figure 3, the distance of the telecommunication companies from the worst and the best ideal solution are determined by comparing the decision criteria of the company with the worst and the best ideal solution respectively. The distance of the telecommunication companies from the worst ideal solution is determined by comparing the decision criteria of the company with the worst ideal solution. TM shows the shortest distance from the worst ideal solution with a value of 0.116848 . This implies that the distance of TM from the worst ideal solution is the closest among the telecommunication companies in this study. On the other hand, the distance from the worst ideal solution for other companies in ascending order are AXIATA (0.168369), MAXIS (0.182883) and DIGI (0.276841). In this study, DIGI has the longest distance from the worst ideal solution compared to other telecommunication companies.

The distance of the telecommunication companies to the best ideal solution is determined by comparing the decision criteria of the company with the best ideal solution. DIGI has the least distance from the best ideal solution (0.041303) among the other telecommunication companies. This implies that DIGI is closed to the best ideal solution. On the other hand, TM shows the farthest distance from the best ideal solution with a value of 0.259835 . The distance from the best ideal solution for AXIATA and MAXIS are 0.225444 and 0.183117 respectively.

The optimal solution which is relative closeness distance of each decision alternative to the ideal solution, siw for overall financial performance is shown in Table 5. The higher value of relative closeness to the ideal solution, siw indicates higher performance of the company.

Table 5. Financial Performance of the Telecommunication Companies in Malaysia

\begin{tabular}{lcc}
\hline Company & Relative Closeness to the Ideal Solution, $s_{i w}$ & Rank, T \\
\hline DIGI & 0.8701741 & 1 \\
MAXIS & 0.4996808 & 2 \\
AXIATA & 0.4275351 & 3 \\
TM & 0.3102026 & 4 \\
\hline
\end{tabular}

Based on Table 5, DIGI gives the highest value of relative closeness to the ideal solution (0.8701741) among the listed telecommunications companies in Malaysia. Therefore, DIGI achieves the first ranking among the four listed telecommunication companies in this study. The relative closeness to the ideal solution for MAXIS, AXIATA and TM are 0.4996808, 0.4275351 and 0.3102026 respectively. The ranking from second to fourth are achieved by MAXIS, AXIATA and TM respectively. In this study, TOPSIS model is able to rank the financial performance of listed telecommunication companies in Malaysia with the proposed conceptual framework.

\section{CONCLUSION}

In this study, a conceptual framework is proposed to evaluate the financial performance of the listed telecommunication companies in Malaysia with TOPSIS model. DIGI achieves the first ranking among the four listed telecommunication companies in Malaysia, followed by MAXIS, AXIATA and TM. This study is 
significant because it helps to evaluate, compare and rank the financial performance of the telecommunication companies in Malaysia by considering the significant financial ratios with TOPSIS model. Besides that, the best ideal and worst ideal solutions for each finantial ratio can serve as the benchmark to the telecommunication companies for further improvement.

\section{ACKNOWLEDGEMENTS}

The authors express gratitude to Universiti Tunku Abdul Rahman (UTAR) for the sponsorship.

\section{REFERENCES}

[1] Q. Kong, G. Chen and G. Holliman, "Telecommunication Service Managment," Data Communications OpenView Advisor, vol. 1, no. 8, Aug 1995.

[2] A. J. X. Lai, W. H. Lam and W. S. Lam, "Optimization on the credit risk of companies in Malaysia with Data Envelopment Analysis model," International Journal of Engineering and Technology, vol. 7, no. 4.11, pp. 13-16, 2018.

[3] W. S. Lam, K. F. Liew and W. H. Lam, "Investigation on the efficiency of financial companies in Malaysia with Data Envelopment Analysis model,” Journal of Physics: Conference Series, vol. 995, 012021, pp. 1-10, 2018.

[4] W. S. Lam, K. F. Liew and W. H. Lam, "An empirical comparison on the efficiency of healthcare companies in Malaysia with Data Envelopment Analysis model," International Journal of Service Science, Management and Engineering, vol. 4, no. 1, pp. 1-5, 2017.

[5] V. M. Dalfard, A. Sohrabian, A. M. Najafabadi and J. Alvani, "Performance evaluation and prioritization of leasing companies using the super efficiency Data Envelopment Analysis model," Acta Polytechnica Hungarica, vol. 9, no. 3, pp. 183-194, 2012.

[6] L. Zamani, R. Beegam and S. Borzoian, "Portfolio selection using Data Envelopment Analysis (DEA): A case of select Indian investment companies," International Journal of Current Research and Academic Review, vol. 2, no. 4, pp. 50-55, Apr. 2014.

[7] S. Hasanloo, E. Karim, M. R. Mehregan and R. Tehrani, "Evaluating performance of companies by new management tools," Journal of Natural and Social Sciences, vol. 2, no. 3, pp. 165-169, 2013.

[8] B. K. Bulgurcu, "Application of TOPSIS technique for financial performance evaluation of technology firms in Istanbul Stock Exchange Market," Procedia - Social and Behavioral Sciences, vol. 62, pp. 1033 - 1040, 2012.

[9] W. H. Lam, W. S. Lam and K. F. Liew, "Improvement on the efficiency of technology companies in Malaysia with Data Envelopment Analysis model," Lecture Notes in Computer Science, vol. 10645, no. 1, pp. 19-30, 2017.

[10] B. B. Yilmaz and A. M. Konyar, "Financial performance evaluation of publicly held lodging companies listed in Istanbul Stock Exchange with TOPSIS method," European Journal of Scientific Research, vol. 95, no. 1, pp. 143$151,2013$.

[11] H. Kazan and O. Ozdemir, "Financial performance assessment of large scale conglomerates via TOPSIS and CRITIC methods," International Journal of Management and Sustainability, vol. 3, no. 4, pp. 203-224, 2014.

[12] A. V. Cam, H. Cam, S. Ulutas and O. B. Sayin, "The role of TOPSIS method on determining the financial performance ranking of firms: An application in the Borsa Istanbul," International Journal of Economics and Research, vol. 6, no. 3, pp. 29-38, 2015.

[13] W. S. Lam, K. F. Liew and W. H. Lam, "An optimal control on the efficiency of technology companies in Malaysia with Data Envelopment Analysis model," Journal of Telecommuncation, Electronic and Computer Engineering, vol. 10, no. 1, pp. 107-111, 2018

[14] M. A. M. Kabajeh, S. M. A. A. Nu'aimat and F. N. Dahmash, "The relationship between the ROA, ROE and ROI ratios with Jordanian Insurance Public Companies market share prices," International Journal of Humanities and Social Science, vol. 2, no. 11, pp. 115-120, Jun. 2012.

[15] C. L. Hwang and K. Yoon, Multiple Attribute Decision Making. Berlin: Springer-Verlag, 1981.

[16] X. Qin, G. Huang, A.Chakma, X.Nie and Q. Lin, "A MCDM-based expert system for climate-change impact assessment and adaptation planning - A case study for the Georgia Basin, Canada," Expert Systems with Applications, vol. 34, no. 3, pp. 2164-2179, 2008.

[17] Y. Ic, "An experimental design approach using TOPSIS method for the selection of computer-integrated manufacturing technologies," Robotics and Computer-Integrated Manufacturing, vol. 28, no. 2, pp. 245-256, 2012.

[18] G. İşseveroğlu and O. Sezer, "Financial performance of pension companies operating in Turkey with Topsis analysis method," International Journal of Academic Research in Accounting, Finance and Management Sciences, Vol. 5, no. 1, pp. 137-147, 2015.

[19] Bursa Malaysia, Company Announcements Bursa Malaysia Market. [online] Available at: $<$ http://www.bursamalaysia.com/market/listed-companies/company-announcements/\#/?category=all> [Accessed 22 February 2017].

[20] C. P. Jones, Investments Analysis and Management. 12nd ed. Denmark: John Wiley \& Sons, 2013. 


\section{BIOGRAPHIES OF AUTHORS}

\begin{tabular}{|l|l|}
\hline & $\begin{array}{l}\text { Dr. Lam Weng Hoe is an Assistant Professor from Faculty of Science, Universiti Tunku Abdul } \\
\text { Rahman (UTAR), Malaysia. He is also Head of Department of Physical and Mathematical } \\
\text { Science, UTAR. His areas of expertise are Econometrics, Optimization, Mathematical and } \\
\text { Statistical Modelling, Portfolio Optimization, Data Envelopment Analysis and Financial } \\
\text { Modelling. }\end{array}$ \\
\hline & $\begin{array}{l}\text { Dr. Lam Weng Siew is an Assistant Professor from Department of Physical and Mathematical } \\
\text { Science, Faculty of Science, Universiti Tunku Abdul Rahman (UTAR), Malaysia. He is also } \\
\text { Head of Programme for postgraduate programmes in Faculty of Science, UTAR. In addition, he } \\
\text { is a PSMB Certified Trainer as well as SAS Certified Statistical Business Analyst. His areas of } \\
\text { expertise are Optimization, Mathematical and Statistical Modelling, Portfolio Optimization, } \\
\text { Financial Modelling, Risk Management, Data Envelopment Analysis and Data Analytics. }\end{array}$ \\
\hline & $\begin{array}{l}\text { Mr. Liew Kah Fai is a lecturer from Department of Physical and Mathematical Science, Faculty } \\
\text { of Science, Universiti Tunku Abdul Rahman (UTAR), Malaysia. His areas of expertise are Data } \\
\text { Envelopment Analysis, Optimization and Statistical Modelling. }\end{array}$ \\
\hline
\end{tabular}

